\title{
A collodiaphysealis szög vizsgálata gerincferdülés esetén, háromdimenziós képalkotás segítségével
}

\author{
DR. BURKUS MÁTÉ1,2, JÓZSEF KRISTÓF ${ }^{1}$, DR. NIKLAI BÁLINT'1, \\ DR. MÁRKUS ISTVÁN ${ }^{1}$, DR. TUNYOGI-CSAPÓ MIKLÓS ${ }^{1}$
}

\section{ÖSSZEFOGLALÁS}

A gerincferdülés, mint összetett térbeli deformitás, kihatással rendelkezik az alsó végtagokra is. Jelen vizsgálat célja volt a collodiaphysealis szög scoliosis melletti értékelése háromdimenziós röntgen képalkotás használatával. A szerzők a Pécsi Tudományegyetem Ortopédiai Klinikájának ambuláns beteganyagából kiválasztott 300 fiatal, serdülőkori, ismeretlen eredetű gerincferdülés diagnózisú eset rutin EOS 2D/3D felvételét dolgozták fel. A sterEOS szoftver segítségével történt görbületi súlyosság meghatározást követően elkészítették mindkét combcsont standard háromdimenziós felszíni rekonstrukcióját, majd megtörtént a kapott collodiaphysealis szög értékek statisztikai összehasonlítása egy korábban már feldolgozott, gerincbetegségtől mentes, kontroll csoporttal. A két csoport közti collodiaphysealis szög értékek eredményei szignifikáns különbséget mutattak ( $p<0,001)$, mely a Cobb szöggel korrelált. A bal és jobb oldali szögek összehasonlítása során a görbületi konvexitásnak megfelelő oldali combnyak állása szignifikánsan varus irányba billent. Jelen vizsgálat tapasztalatai szerint a fiatalkori ismeretlen eredetű gerincferdülés kimutatható varizáló hatással rendelkezik a collodiaphysealis szögre, mely a fő görbület felőli oldalon jelentkezik. A szerzők az eredmények hátterében a deformitás okozta megváltozott mechanikai hatást feltételezik.

\section{Kulcsszavak:}

\section{Gerincferdülés; Háromdimenziós képalkotás; Radiográfiai módszerek; Scoliosis;}

M. Burkus, K. József, B. Niklai, I. Márkus, M. Tunyogi-Csapó: Collodiaphyseal angle assessment in scoliosis with three dimensional imaging

Scoliosis, as a spatial deformity, has effect on lower limbs. The present study was aimed to assess the collodiaphyseal angle in scoliosis, with three-dimensional X-ray system. Routine EOS 2D/3D radiography of 300 young cases, with the diagnosis of adolescent idiophatic scoliosis, was selected from the database of our Orthopaedic Department. After the curve evaluation, given by the sterEOS software, three dimensional surface reconstruction of both femur has been performed. The measured collodiaphyseal angle values were statistically analysed, and compared to a previously assessed control group without spinal deformity. In the results, collodiaphyseal angle parameters are significantly $(p<0,001)$ lower in scoliosis than in the control group, and correlates with the magnitude of the deformity. Comparing the left and right side, the femoral neck shaft values significantly tend to varus on the convex side. According to the results adolescent idiophatic scoliosis has a potentional varisating effect on collodiaphyseal angle, where the altered mechanical effects are assumed as a background.

Key words: $\quad$ Imaging, three-dimensional-Methods; Radiography-Methods; Scoliosis - Radiography; Spine - Radiography; 


\section{BEVEZETÉS}

A serdülőkori ismeretlen eredetű gerincferdülés az egyik leggyakoribb gerincet érintő elváltozás, amely a populáció $1-2 \%$-ában is jelen lehet. A betegség elsődleges problémát a frontális síkban okoz. Ez azonban nem csak egy laterális irányú elhajlást jelent, hanem a tér mindhárom síkját érintő összetett deformitást, mely közvetetten befolyással rendelkezik az egész szervezetre, így az alsó végtagokra is.

A scoliosis jelenléte mellett a testet érintő aszimmetriákat több közlemény is taglalja. Normelli és munkatársai 18 normál és 15 gerincferdüléses cadaver összehasonlítása során a bordák hosszában szignifikáns különbséget észleltek, amely azok hamu tömegében már nem volt kimutatható (21). Burwell és munkatársai által tapasztaltak szerint háti görbület esetén a felkar relatív hosszabb a konvexitás oldalán, valamint az ágyéki vagy háti-ágyéki átmenetet érintő görbületnél a jobb alsó végtag is relatív hosszabb $(4,5)$. A röntgenen észlelhető medencefél aszimmetriát vizsgálva Gum és munkatársai, illetve Qiu és munkatársai csontos deformációt nem találtak, az eltérés hátterében transversalis síkú medence rotációt igazoltak, ahol a medence csavarodása a háti görbülettel megegyező oldalra mutatott (15, 22 ). A csípő rotációs mozgásainak értékelése során Kotwicki és munkatárasai szignifikánsan több esetben észleltek különbséget a két oldal mozgásterjedelmében gerincferdülés mellett, mint normál csoportnál (18). Ezt erősítették meg Cheung és munkatársai is, vizsgálatukban a bal és jobb oldal adductiós aszimmetriáját 102 gerincferdüléses páciensből 64-nél 5 fokot meghaladónak találták (7).

Megfigyelések alapján felmerült a gyanú, hogy a gerincferdülés kimutatható befolyással rendelkezik az alsó végtagokra, azon belül annak proximalis régiójára, a collodiaphysealis szögre is. Az irodalom áttekintése során a szerzők csupán egy olyan vizsgálatot találtak, amely ezt a paramétert ismeretlen eredetű serdülőkori gerincferdülés mellett értékeli. Saji és munkatársai vizsgálatukban a collodiaphysealis szög értékében egyértelmű különbséget tapasztaltak a scoliosisos és kontroll esetek között (25).
$A z$ alsó végtagok anatómiai paramétereinek meghatározása kiemelt jelentőséggel bír, hiszen azoknak a normális értékekhez viszonyított eltérései változást eredményezhetnek a végtagi biomechanikában, így bizonyítottan összefüggésben állnak számos ortopédiai elváltozás kialakulásával. A collodiaphysealis szög értékeiben észlelt eltérések a coxarthrosis független rizikótényezői között szerepelnek (8).

A proximalis femur régió vizsgálatára, így a paraméterek meghatározására korábban, bizonyos komplex képalkotási lehetőségeket, mint CT vagy MR-t leszámítva, nem állt rendelkezésre kellő pontosságú eljárás. Georges Charpak 1992-ben Nobel díjjal jutalmazott röntgen detektálási elvén alapuló képalkotási technika, az EOS 2D/3D (EOS Imaging, Paris, France), forradalmi változást hozott a gerinc és az alsó végtagok röntgen alapú vizsgálatában (6). A készülék álló testhelyzetben, teljes terheléssel, szimultán végez antero-posterior és lateralis képalkotást, ultra alacsony sugárterhelés mellett. A kalibrált térben történő kettős leképezés alapot biztosít a gerinc, illetve az alsóvégtagok nagy pontosságú, háromdimenziós, felületi megjelenítésére, a kapcsolt SterEOS 3D rekonstrukciós program segítségével, ami olyan klinikai paraméterek meghatározását tette lehetővé, amelyek a korábbi konvencionális 2D ábrázolás során nem voltak megjeleníthetők (10). A létrehozott felületi modellek, normál csontstruktúra és bizonyos deformációk esetén is, a CT-hez hasonló képet biztosítanak, annál lényegesen, akár 800-1000 szer kisebb sugárterhelés használatával $(11,14,31)$. A készülék, valamint a rekonstrukciós program használhatóságát és pontosságát, a mindennapi ortopéd gyakorlatban, már számos vizsgálat bizonyította mind a gerinc, mind az alsó végtagok tekintetében, többek között intézetünkben is $(16,17$, 26-28, 30, 34).

Jelen vizsgálatunk célja volt, hogy a serdülőkori ismeretlen eredetű gerincferdülés mellett értékelje a proximalis femur régió kiemelt paraméterét, a collodiaphysealis szöget. Meghatározva ezzel a deformitásnak a régióra kifejtett hatását, egy bizonyítottan nagy pontosságú röntgen képalkotás segítségével, nagy esetszámnál. 


\section{ANYAG ÉS MÓDSZER}

Vizsgálatunkhoz a Pécsi Tudományegyetem Ortopédiai Klinikájának ambuláns radiológiai adatbázisának beteganyagát használtuk fel. 2007-ig visszamenően választottunk ki adolescens idiophatiás scoliosisos (AIS) eseteket. Kizártunk minden egyéb etiológiájú gerincelváltozást, illetve azokat is, ahol bármilyen, a gerincet és az alsó végtagokat érintő korábbi sebészeti beavatkozás történt. Az összehasonlításba végül 300 fiatalt (69 fiú 231 lány) vontunk be, átlagéletkor $15,0 \pm 2,3$ megoszlás 10-18 év volt.

Minden képalkotás ortopéd indikációval történt, gerincferdülés miatt, az intézetünkben 2007-óta rutinszerűen klinikai használatban lévő EOS 2D/3D készülék segítségével. A vizsgálatok előtt a páciensek, illetve törvényes képviselőik, írásos beleegyezésben járultak hozzá annak elvégzéséhez, illetve az adatok később kutatási célú felhasználhatóságához.

A kritériumoknak megfelelő beteganyag összegyűjtését követően minden esetben elvégeztük a gerincgörbületek és azok Cobbszögének SterEOS alapú meghatározását, majd mindkét femur 3D felszíni modellezését. A térbeli modell alapú számítógépes paraméter meghatározás kiküszöböli a femoralis torzió miatti, valamint a konvencionális képalkotás során megjelenő vetülési torzítás mérési hibáit, így nagy pontosságú eredményt ad. A rekonstrukciók elkészítése az abban nagy gyakorlattal rendelkező PhD hallgatók által történtek a SterEOS 3D V1.4.4.5297 (EOS Imaging, Paris, France) szoftver használatának segítségével (1. ábra).

A modellalkotások során az interobszerver hiba és intraobszerver megbízhatóság értékelésére 30 random kiválasztott gerinc, illetve mindkét oldali femur 3D modelljének, három független alkalommal történő elkészítése során került sor. A csoportok közti kapcsolatot a Winter kritériumok szerint értékeltük: 0-tól 0.24-ig nincs vagy gyenge megbízhatóság, 0.25től 0.49-ig alacsony, 0.50-től 0.69-ig közepes, 0.7-től 0.89-ig jó, míg 0.90 felett kitűnő (32).
A görbületek Cobb-szöge alapján, a 2011-es SOSORT guideline alapján (20), elvégeztük az esetek négy súlyossági csoportba történő besorolását. 1-es csoport: 15-25 fok (enyhe), $\mathrm{n}=116$ (32 fiú - 84 lány); 2-es csoport: 25-45 fok (középsúlyos), $n=98$ (20 fiú -78 lány); 3-as csoport: 45-60 fok (súlyos), $n=46$ (7 fiú - 39 lány); 4-es csoport: 60 fok felett (nagyon súlyos), $n=40$ (10 fiú - 30 lány).

A feldolgozott eseteket a görbületek konvexitásának iránya alapján is csoportosítottuk, amit elősegített, hogy a SterEOS program a Cobb-szög mérés során a görbületek irányát is megadja. Amennyiben a szög értéke pozitívnak mutatkozott, a fő görbület balra konvex ágyéki volt ( $n=141$ eset), negativ érték pedig jobbra konvex háti görbületet ( $\mathrm{n}=159$ eset) jelentett. Így lehetőségünk nyílt a bal és jobb oldali collodiaphysealis paraméterek és a görbületi irányultság viszonyának megvizsgálására is.

A vizsgáltunk kontrolljaként, intézetünk korábbi gerincelváltozással nem rendelkező eseteket tartalmazó adatbázisát használtuk fel. Innen választottuk ki a korban és nemi eloszlásban megfelelő kontroll csoportot, amely végül 350 főt foglalt magába (81 fiú, 269 lány),

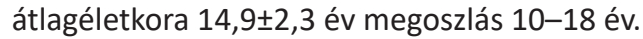

A sterEOS 3D rekonstrukciós szoftver segítségével a femur modelljének elkészítését követően összesen nyolc paramétere határozható meg, melyek közül jelen vizsgálat csak a collodiaphysealis szöget értékelte.

A kapott adatok feldolgozását az SPSS v22 (IBM Corp., Armonk, NY, USA) és Microsoft Office Professional Plus v14.0.6112.5000 (Microsoft Corp., Redmond, WA, USA) programcsomagokkal végeztük. Statisztikai elemzés során az értékek eloszlását a Kolmogorov-Smirnov teszttel vizsgáltuk. A kontroll és a gerincferdüléses csoportok közötti eltéréseket független mintás t-próba segítségével határoztuk meg. A Cobb-szög és a collodiaphysealis szög kapcsolatát Spearman korreláció alapján értékeltük. $\mathrm{Az}$ oldalkülönbségeket páros $\mathrm{t}$-próbával hasonlítottuk össze. Az eredményeknél a $p<0,05$ értéket tekintettük szignifikánsnak. 


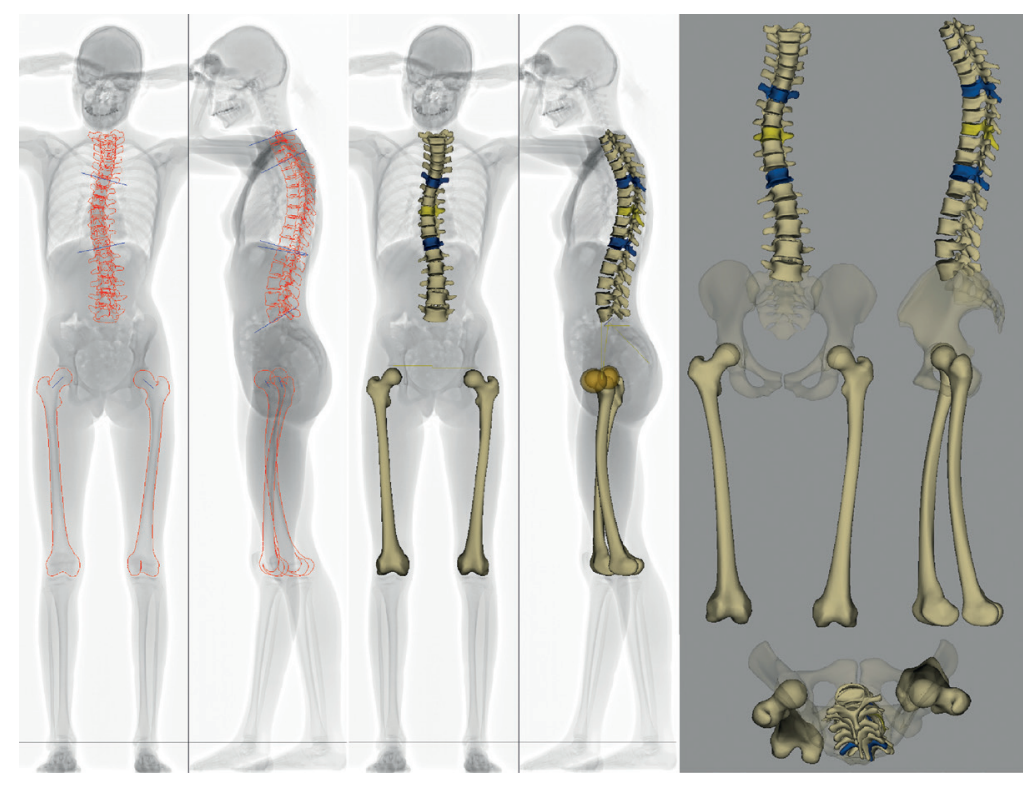

1. ábra KK, 13 éves lány gyermek gerinc és mindkét oldali combcsont teljes felszíni rekonstrukcióját mutatja. A jobbra konvex háti görbület a T6-T9-T12 csigolyák között áll fenn. Cobb-szög értéke 32,3 fok (súlyossági csoport: 2-es). A collodiaphysealis szög jobb oldalon 119,2 fok, bal oldalon 121,2 fok

\section{EREDMÉNYEK}

A rekonstrukciók elkészítése során az intraés interobserver megbízhatóság minden paraméter tekintetében 0,9 feletti értéket adott a Winter kritériumok szerint, így mindvégig kitűnőnek bizonyult. A Kolmogorov-Smirnov teszt alapján a paraméterek normál eloszlásúnak mutatkoztak. A Cobb-szögek abszolút értékének átlaga $36 \pm 21$ fok, szórás $15-123$ fok volt.

A 300 gerincferdüléssel rendelkező és a 350 kontrollként használt esetnél kapott collodiaphysealis paramétereket az $I$. táblázatban foglaltuk össze. A két csoportot összehasonlítva (kontroll 129,6 $\pm 4,5$ fok; gerincferdülés $128,2 \pm 6,6$ fok) szignifikáns különbség ( $p<0,001)$ igazolódott. A különböző súlyosságú csoportokat külön-külön vizsgálva is hasonlóan szignifikáns különbséget találtunk a kontrollcsoporthoz képest (pmax $=0,011$ ), egymástól azonban nem tértek el jelentősen (2. ábra). Spearman korrelációval sem találtunk szignifikáns kapcsolatot a collodiaphysealis szög és Cobb-szög nagysága között.

A görbületi irány alsó végtagokra gyakorolt hatásának értékeléséhez a Cobb-szög értékét (balra konvex fő görbület esetében értéke pozitív, jobbra konvexnél negatív) vetettük össze a két oldal közötti különbséggel (minden paraméter esetében bal oldali végtagnál kapott értékből vontuk ki a jobb oldal értékét). Spearman korreláció használatával, amely során szignifikáns kapcsolatot találtunk (Korrelációs koefficiens $=-0,223, p<0,001$ ).

A két oldal közti különbségeket páros mintás t-próbával is összevetettük (különkülön a jobbra és balra konvex fő görbületek esetében), ami szintén szignifikáns eredményt adott ( $p=0,037$ bal, illetve $p<0,001$ jobb). Öszszefoglalva: abban az esetben, ha balra konvex a fö görbület a bal oldali combnyak varusosabb helyzetü, illetve, ha jobbra konvex a fö görbület, a jobb oldali combnyak helyzete billen jobban varus irányba (3. ábra). 


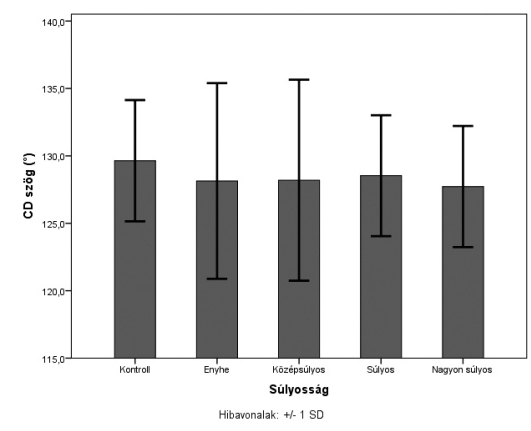

2. ábra CD szög értékek a súlyossági csoportok függvényében (átlag士S.D.) *: szignifikáns különbség $(p<0,05)$

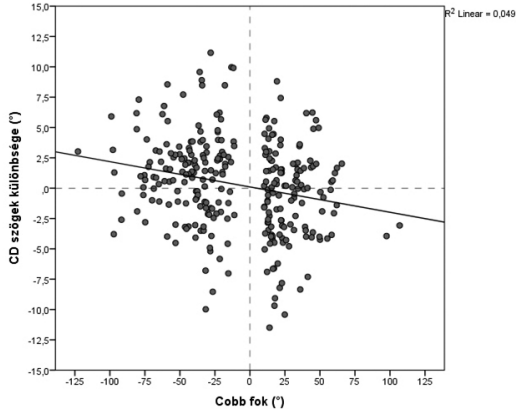

3. ábra Oldalkülönbségek

Boxplot diagram a Cobb-szög (pozitiv, ha balra és negativ, ha jobbra konvex a görbület) és a két oldal különbségét (balból kivonva a jobbat) mutatja.

I. táblázat A kontroll és a gerincferdüléssel rendelkező esetek, valamint azok súlyosság szerint felosztott csoportjainak átlagéletkora és $C D$ szög eredményei

\begin{tabular}{|c|c|c|c|c|c|c|}
\hline & Kontroll & Scoliosis & T-próba & Enyhe & Középsúlyos & Súlyos \\
\hline $\mathbf{n}$ (fö) & 350 & 300 & $350 / 300$ & 116 & 98 & 46 \\
\hline $\begin{array}{c}\text { Életkor (év) } \\
\text { Collodiaphysealis }\end{array}$ & 14,9 & 15,0 & & 14,9 & 15,3 & 15,1 \\
\hline $\begin{array}{c}\text { szög } \\
\text { (átlag } \pm \text { S.D., fok) }\end{array}$ & $129,6 \pm 4,5$ & $128,2 \pm 6,6$ & $\mathbf{p r 0 , 0 0 1}$ & $128,1 \pm 7,3$ & $128,2 \pm 7,5$ & $128,5 \pm 4,5$ \\
\hline
\end{tabular}

\section{MEGBESZÉLÉS}

Vizsgálatunk célja a serdülőkori ismeretlen eredetű gerincferdülés jelenléte mellett észlelt collodiaphysealis szög értékek maghatározása, ezáltal a deformitásnak az alsó végtagok proximalis régiójára kifejtett hatásának értékelése volt.

$A z$ ismeretlen etiológiájú scoliosis, amely elsődlegesen a gerincet érintő elváltozás, következményes hatással rendelkezik az egész szervezetre, amely aszimmetriákat több közlemény is taglalja $(4,5,7,18,21)$.

$\mathrm{Az}$ alsó végtagok proximalis régiójának pontos vizsgálata, fizikális módszerekkel (12, 19) nem kivihető. A rutinszerűen alkalmazott röntgen alapú eljárások is korlátozottan használhatók a vetülésből és pozícionálásból adódó hibák miatt $(2,3,9,28,32)$. Az olyan komplex képalkotók, mint $C T$ vagy MR mindennapi rutin felhasználása szintén nem megoldható. Az EOS 2D/3D alacsony sugárdózisú teljes test röntgen szkenner lehetővé teszi a gerinc, valamint a subpelvicus régió egységként történő nagy pontosságú értékelését. A diagnosztikai eszköz alkalmazhatóságát, gyermek-, illetve serdülőkorban mind a gerinc, mind az alsó végtag tekintetében is számos vizsgálat bizonyította, többek között intézetünkben is $(1,13,14,17$, $23,24,27,28,30,31)$.

A collodiaphysealis szög életkorral kapcsolatos csökkenést intézetünk korábbi 508 4-16 év között gyermeken végzett vizsgálata 131,0 fokról 127,4 fokra írta le fiúk, és 129,8 fokról 128,8 fokra lányok esetén (30). Az eredmények, bár abszolút értékben kisebbek, de változási tendenciájukban egyezést mutattak Birkenmaier és munkatársai konvencionális radiológiai képalkotással végzett tanulmányának eredményeivel (145 fokról 135 fokra, 16 éves korig). Vizsgálatuk szerint a szög értéke gyakorlatilag 10 éves korra stabilizálódni látszik (2).

Jelen vizsgálat eredményei szerint a kontrollcsoportnál tapasztalt $129,6 \pm 4,5$ fokos, illetve a gerincferdülés melletti 128,2 $\pm 6,7$ fokos collodiaphysealis szög érték statisztikailag szignifikánsan $(p<0,001)$ eltér. Ez az eredmény egyértelmúen ellentmondásban 
áll Saji és munkatársai által 94 (61 AIS és 33 kontroll) kínai lány standard antero-posterior röntgenfelvételének feldolgozása alapján készült publikációjával. Ők gerincferdülés mellett szignifikánsan magasabb CD szög értékeket találtak (kontroll 129,5 $\pm 3,7$ fok bal, és $129,9 \pm 3,7$ fok jobb; gerincferdülés: $137,5 \pm 6.6$ fok bal, és $137,9 \pm 5,5$ fok jobb oldalon) (25).

A bal és jobb oldali collodiaphysealis szög értékeket a görbületek konvexitásának függvényében is külön értékeltük, ezáltal pontosítva a gerincferdülésnek az alsó végtagokra kifejtett hatását. Tapasztalataink szerint amennyiben a görbület balra konvexitást mutat, ( $n=141$ eset) a CD szög bal oldali $128,4 \pm 4,8$ fok értéke szignifikánsan kisebb, mint a jobb oldalon tapasztalt $129,1 \pm 5,1$ fok. Jobbra konvex görbület esetén (159 eset) a bal oldali 129,0 $\pm 4,7$ fok szignifikánsan magasabb, mint a jobb oldalon $127,8 \pm 4,8$ fok. Mindezt összefoglalva, eredményeink szerint a görbületek konvexitásával megegyező oldali CD szög varus irányba billen, míg az ellenoldali - feltehetően kompenzációként - inkább valgus irányba változik.

Jelen vizsgálat eredményei bizonyítékul szolgálnak, hogy a serdülőkori ismeretlen eredetű gerincferdülés egyértelmű hatással van a femur proximalis régiójára. Az általunk a collodiaphysealis szög esetén tapasztalt csökkent értékek ellentmondanak a korábban más tanulmány által talált emelkedő tendenciának. Eredményeink szerint a gerincferdülés esetén összességben is varizáló tendencia figyelhető meg, amely a görbület konvexitásának oldalán kifejezettebb. Az eltérések hátterében a deformitás okozta megváltozott biomechanikai és élettani hatást, az aszimmetrikus mechanikai terhelést feltételezzük. A serdülőkori gerincferdülés kialakulása jellemzően a második évtized elejére tehető, mely életszakaszra az alsó végtagok fejlődése - így a paraméterek alakulása is - már nagyrészt lezárult, ahogy azt a korábbi vizsgálatok bizonyították $(2,30)$. Az elváltozás e fejlődési ciklus végén, illetve utána alakul ki, így a következményes deformáló hatás már csak kisebb mértékben, de egyértelműen kimutatható.

A vizsgálat során tapasztaltakat, a mechanikai aszimmetria deformáló hatásának tényleges jelenlétét, fiatalabb (10 éves kor előtti) gerincferdüléssel rendelkező csoport vizsgálata tudná alátámasztani, hiszen ebben az időszakban az alsó végtag paraméterei még aktívan változnak. Az ilyen, early onset scoliosis melletti összehasonlítás elkészítését limitálja, hogy a korai esetek elfordulása az összes gerincferdüléses esethez viszonyítva ritka, továbbá közöttük kevés a strukturális vagy idiopathiás eredettel kialakult deformitás. Hátterükben nagy eséllyel azonosítható egyértelmű összetett kiváltó ok, amely alapbetegségek önmagukban is deformáló hatással lehetnek az alsó végtagokra, így a mechanikai hatás elkülönítése nem lehetséges.

Eredményeinket limitálhatja, hogy a kontrollcsoport sem teljesen mentes ortopédiai panasztól. Teljesen panaszmentes, egészséges, fiatal egyének kutatási célú sugárterheléssel járó vizsgálata - még ilyen alacsony dózis esetében is - etikai kérdéseket vet fel.

\section{Köszönetnyilvánítás:}

A jelen tudományos közleményt a szerzők a Pécsi Tudományegyetem alapításának 650. évfordulója emlékének szentelik. A tanulmány megvalósulását a GINOP-2.3.2-15-2016-00022, 3D nyomtatási és vizualizációs technológiákat alkalmazó interdiszciplináris kutatási, oktatási és fejlesztési központ kialakítása a Pécsi Tudományegyetemen projekt támogatta. 


\section{IRODALOM}

1. Assi A., Chaibi Y., Presedo A., Dubousset J., Ghanem I., Skalli W.: Three-dimensional reconstructions for asymptomatic and cerebral palsy children's lower limbs using a biplanar X-ray system: a feasibility study. Eur. J. Radiol. 2013. 82. (12): 23592364. https://doi.org/10.1016/i.ejrad.2013.07.006

2. Birkenmaier C., Jorysz G., Jansson V., Heimkes B.: Normal development of the hip: a geometrical analysis based on planimetric radiography. J. Pediatr. Orthop. B. 2010. 19.(1): 1-8. https://doi.org/10.1097/BPB.0b013e32832f5aeb

3. Bonneau N., Libourel P.A., Simonis C., Puymerail L., Baylac M., Tardieu C., Gagey O.: A three-dimensional axis for the study of femoral neck orientation. J. Anat. 2012. 221. (5): 465-476. https://doi.org/10.1111/i.1469-7580.2012.01565.x

4. Burwell R. G.., Aujla R. K., Freeman B. J., Dangerfield P. H., Cole A. A., Kirby A. S., Pratt R. K., Webb J. K., Moulton A.: Patterns of extra-spinal left-right skeletal asymmetries and proximo-distal disproportion in adolescent girls with lower spine scoliosis: ilio-femoral length asymmetry \& bilateral tibial/foot length disproportion. Stud. Health Technol. Inform. 2006. 123: 101-108.

5. Burwell R.G.., Freeman B. J., Dangerfield P. H., Aujla R.K., Cole A.A., Kirby A.S., Pratt R. K., Webb J. K., Moulton A.: Left-right upper arm length asymmetry associated with apical vertebral rotation in subjects with thoracic scoliosis: anomaly of bilateral symmetry affecting vertebral, costal and upper arm physes? Stud. Health Technol. Inform. 2006. 123: 66-71.

6. Charpak G..: Prospects for the use in medicine of new detectors of ionizing radiation. Bull. Acad. Natl. Med. 1996. 180. (1): 161-168.

7. Cheung K.M., Cheng A.C., Cheung W.Y., Chooi Y.S., Wong Y.W., Luk K.D.: Right hip adduction deficit and adolescent idiopathic scoliosis. J. Orthop Surg. (Hong Kong). 2008. 16. (1): 24-26. https://doi.org/10.1177/230949900801600106

8. Chitnavis J., Sinsheimer J. S., Suchard M. A., Clipsham K., Carr A. J.: End-stage coxarthrosis and gonarthrosis. Aetiology, clinical patterns and radiological features of idiopathic osteoarthritis. Rheumatology (Oxford). 2000. 39. (6): 612-619. https://doi.org/10.1093/rheumatology/39.6.612

9. Cooke T. D., Scudamore R. A., Bryant J. T., Sorbie C., Siu D., Fisher B.: A quantitative approach to radiography of the lower limb. Principles and applications. J. Bone Joint Surg. Br. 1991. 73. (5): 715-720.

10. Deschênes S., Charron G., Beaudoin G., Labelle H., Dubois J., Miron M. C., Parent S.: Diagnostic imaging of spinal deformities: reducing patients radiation dose with a new slot-scanning X-ray imager. Spine (Phila Pa 1976). 2010. 35. (9): 989-994. https://doi.org/10.1097/BRS.0b013e3181bdcaa4

11. Dietrich T. J., Pfirrmann C. W., Schwab A., Pankalla K., Buck F. M.: Comparison of radiation dose, workflow, patient comfort and financial break-even of standard digital radiography and a novel biplanar low-dose $X$-ray system for upright full-length lower limb and whole spine radiography. Skeletal Radiol. 2013. 42. (7): 959-967. https://doi.org/10.1007/s00256-013-1600-0

12. Engel G. M., Staheli L. T.: The natural history of torsion and other factors influencing gait in childhood. A study of the angle of gait, tibial torsion, knee angle, hip rotation, and development of the arch in normal children. Clin. Orthop. Relat. Res. 1974. (99): 12-17. https://doi.org/10.1097/00003086-197403000-00002

13. Gaumétou E., Quijano S., Ilharreborde B., Presedo A., Thoreux P., Mazda K., Skalli W.: EOS analysis of lower extremity segmental torsion in children and young adults. Orthop. Traumatol. Surg. Res. 2014. 100. (1): 147-151. https://doi.org/10.1016/i.otsr.2013.09.010

14. Gheno R., Nectoux E., Herbaux B., Baldisserotto M., Glock L., Cotten A., Boutry N.: Three-dimensional measurements of the lower extremity in children and adolescents using a low-dose biplanar X-ray device. Eur. Radiol. 2012. 22. (4): 765-771. https://doi.org/10.1007/s00330-011-2308-y

15. Gum J. L., Asher M. A., Burton D. C., Lai S. M., Lambart L. M.: Transverse plane pelvic rotation in adolescent idiopathic scoliosis: primary or compensatory? Eur. Spine J. 2007. 16. (10): 1579-1586. https://doi.org/10.1007/s00586-007-0400-4

16. Illés T., Somoskeöy S.: Az EOS ${ }^{\mathrm{TM}}$ röntgengép elve és gyakorlati használata a mindennapi ortopédiai gyakorlatban. Orv. Hetil. 2012. 153. (8): 289-295. https://doi.org/10.1556/OH.2012.29312

17. Illés T., Somoskeöy S.: The EOS ${ }^{\top M}$ imaging system and its uses in daily orthopaedic practice. Int. Orthop. 2012. 36. (7): 13251331. $\mathrm{https://doi.org/10.1007/s00264-012-1512-y}$

18. Kotwicki T., Walczak A., Szulc A.: Trunk rotation and hip joint range of rotation in adolescent girls with idiopathic scoliosis: does the "dinner plate" turn asymmetrically? Scoliosis. 2008. 3. 1. https://doi.org/10.1186/1748-7161-3-1

19. Kraus V. B., Vail T. P., Worrell T., McDaniel G..: A comparative assessment of alignment angle of the knee by radiographic and physical examination methods. Arthritis Rheum. 2005. 52. (6): 1730-1735. https://doi.org/10.1002/art.21100

20. Negrini S., Aulisa A. G., Aulisa L., Circo A. B., de Mauroy J. C., Durmala J., Grivas T. B., Knott P., Kotwicki T., Maruyama T., Minozzi S., O’Brien J. P., Papadopoulos D., Rigo M., Rivard C. H., Romano M., Wynne J. H., Villagrasa M., Weiss H. R., Zaina F.: 2011 SOSORT guidelines: Orthopaedic and Rehabilitation treatment of idiopathic scoliosis during growth. Scoliosis. 2012. 7. 3. https://doi.org/10.1186/1748-7161-7-3

21. Normelli H., Sevastik J., Akrivos J.: The length and ash weight of the ribs of normal and scoliotic persons. Spine (Phila Pa 1976). 1985. 10. (6): 590-592. https://doi.org/10.1097/00007632-198507000-00015

22. Qiu X. S., Zhang J. J., Yang S. W., Lv F., Wang Z. W., Chiew J., Ma W. W, Qiu Y.: Anatomical study of the pelvis in patients with adolescent idiopathic scoliosis. J. Anat. 2012. 220. (2): 173-178. https://doi.org/10.1111/i.1469-7580.2011.01458.x

23. Rosskopf A. B., Buck F. M., Pfirrmann C. W., Ramseier L. E.: Femoral and tibial torsion measurements in children and adolescents: comparison of MRI and 3D models based on low-dose biplanar radiographs. Skeletal Radiol. 2017. 46. (4): 469-476. https://doi.org/10.1007/s00256-017-2569-x 
24. Rosskopf A. B., Ramseier L. E., Sutter R., Pfirrmann C. W., Buck F. M.: Femoral and tibial torsion measurement in children and adolescents: comparison of 3D models based on low-dose biplanar radiography and low-dose CT. AJR Am. J. Roentgenol. 2014. 202. (3): 285-291. https://doi.org/10.2214/AJR.13.11103

25. Saji M. J., Upadhyay S. S., Leong J. C.: Increased femoral neck-shaft angles in adolescent idiopathic scoliosis. Spine (Phila Pa 1976). 1995. 20. (3): 303-311. https://doi.org/10.1097/00007632-199502000-00008

26. Schlégl Á., O'Sullivan I., Varga P., Than P., Vermes C.: Determination and correlation of lower limb anatomical parameters and bone age during skeletal growth (based on 1005 cases). J. Orthop Res. 2017. 35. (7): 1431-1441. https://doi.org/10.1002/jor.23390

27. Schlégl Á., Szuper K., Somoskeöy S., Than P.: Three dimensional radiological imaging of normal lower-limb alignment in children. Int. Orthop. 2015. 39. (10): 2073-2080. https://doi.org/10.1007/s00264-015-2851-2

28. Schlégl A. T., Szuper K., Somoskeöy S., Than P.: Az EOS 2D/3D System alkalmazhatóságának vizsgálata a szabad alsó végtag anatómiai és biomechanikai paramétereinek mérésére gyermekkorban. Orv. Hetil. 2014. 155. (43): $1701-1712$. https://doi.org/10.1556/OH.2014.30009

29. Siu D., Cooke T. D., Broekhoven L. D., Lam M., Fisher B., Saunders G.., Challis T. W.: A standardized technique for lower limb radiography. Practice, applications, and error analysis. Invest. Radiol. 1991. 26. (1): $71-77$. https://doi.org/10.1097/00004424-199101000-00013

30. Szuper K., Schlégl Á., Leidecker E., Vermes C., Somoskeöy S., Than P.: Three-dimensional quantitative analysis of the proximal femur and the pelvis in children and adolescents using an upright biplanar slot-scanning X-ray system. Pediatr. Radiol. 2015. 45. (3): 411-421. https://doi.org/10.1007/s00247-014-3146-2

31. Than P., Szuper K., Somoskeöy S., Warta V., Illés T.: Geometrical values of the normal and arthritic hip and knee detected with the EOS imaging system. Int. Orthop. 2012. 36. (6): 1291-1297. https://doi.org/10.1007/s00264-011-1403-7

32. Thelen P., Delin C., Folinais D., Radier C.: Evaluation of a new low-dose biplanar system to assess lower-limb alignment in 3D: a phantom study. Skeletal Radiol. 2012. 41. (10): 1287-1293. https://doi.org/10.1007/s00256-012-1438-X

33. Winer B.J.: Statistical principles in experimental design. New York. McGraw-Hill. 1962.672 p. https://doi.org/10.1037/11774-000

34. Wybier M., Bossard P.: Musculoskeletal imaging in progress: the EOS imaging system. Joint Bone Spine. 2013. 80. (3): 238243. https://doi.org/10.1016/i.jbspin.2012.09.018

\section{Dr. Burkus Máté}

Petz Aladár Megyei Oktató Kórház, Balesetsebészeti és Kézsebészeti Osztály 9023 Győr, Vasvári Pál u 2-4.

burkusmate@gmail.com 